\title{
Shortcomings in the Workplace Whistleblower Protection in France: What to Expect from the Transposition of Directive 2019/1937?
}

\author{
Gwenola Bargain ${ }^{1}$ \\ https://doi.org/10.18778/8220-639-5.04
}

\section{Introduction}

At first glance, the French legal framework for whistleblower protection may appear to be particularly well developed. Indeed, since the so-called Sapin II Law, ${ }^{2}$ it has offered general criteria to qualify a person as a whistleblower and set procedural and substantive guarantees against possible retaliatory measures. Although advanced, the system is not complete. Its shortcomings are repeatedly mentioned ${ }^{3}$ to the extent that the transposition of the European Directive (EU) 2019/1937 of 23 October $2019^{4}$ is an opportunity to correct the limitations of the current system. ${ }^{5}$

Article 6 of the Sapin II Law does not exactly define whistleblowing or whistleblowers, but it does provide a legal qualification, which implies protection of the whistleblower. It is a matter of revealing or reporting, "in a disinterested manner and in good faith, a crime or misdemeanour, a serious and manifest violation of an international commitment regularly ratified or approved by France, of a unilateral act of an international organization taken on the basis of such a commitment, of the law

1 Associate Professor at the University of Tours.

2 Loi No. 2016-1691 du 9 décembre 2016 relative à la transparence, à la lutte contre la corruption et à la modernisation de la vie économique. Michel Sapin was the Minister of Economy and Finance at the time.

3 See, for example, the communiqués of the Defender of Rights on this subject, https://www. defenseurdesdroits.fr/fr/communique-de-presse/2020/12/la-defenseure-des-droits-appellea-renforcer-la-protection-des-lanceurs, accessed 01/09/2021.

4 Directive (EU) 2019/1937 of the European Parliament and of the Council of 23 October 2019 on the protection of persons who report breaches of Union law.

5 See Opinion of the Defender of Rights No. 20-12: "The Defender of Rights has, in fact, noted numerous gaps and uncertainties in the whistleblower protection system resulting from the Sapin II Law, which the transposition of the directive should make it possible to correct", 16 December 2020, p. 10. 
or of regulations, or a serious threat or prejudice to the general interest" (Article 6). The person who issued the alert must also have personal knowledge of the facts in question. This is not exactly a definition and the list of the objects of this alert is deliberately vague, with the essential criterion being the seriousness of the breach or the threat. However, the progress made is noteworthy since the French legislator is attempting to encompass situations of great variety through a single legal category.

The assimilation of this new legal category is still too recent for the litigation to be significant and, at this stage, the legal term 'whistleblower' remains relatively rare within the jurisprudence. ${ }^{6}$ It should also be noted that a recent and famous case concerns not an employee but a labour inspector, who claimed whistleblower status in the context of the 'Tefal case.' The French concept of the whistleblower status still appears to be in its infancy. The Defender of Rights, an organization in charge of the orientation and protection of whistleblowers, underlined a relatively low number of alerts reported since the adoption of the law. ${ }^{8}$ In order to understand the difficulties faced by persons wishing to launch an alert, it is necessary first of all to question the aims pursued by the legislator in the construction of the whistleblower protection system in France.

It should be remembered that the decision to institute a general framework for the protection of whistleblowers in France was not made suddenly. ${ }^{9}$ The understanding of the content of whistleblowing and its purpose has evolved with the work and reports carried out on the subject. Originally conceived as referring primarily to the person who reveals or denounces a risk to health or the environment, the whistleblower has gradually emancipated from this sole dimension to become part of the public policy issue of transparency. Now, a whistleblower is the person who reveals violations of the law, thus becoming part of the compliance scheme. ${ }^{10}$ Indeed, the protection of whistleblowers has been integrated into the Sapin II Law with a view to fighting corruption and financial offences.

6 See J. Alibert, J.-P. Foegle, Première victoire d'un lanceur d'alerte en référé sous l'empire de la loi «Sapin II», La Revue des droits de l'homme [En ligne], Actualités Droits-Libertés, https:// journals.openedition.org/revdh/6313, accessed 01/09/2021.

7 In this case, a labour inspector had disclosed e-mails to trade unions that she had obtained from an employee of the company. These e-mails had been sent and received in 2013 by the management of a factory and demonstrated collusion between the factory manager and the labour inspector's supervisor regarding the inspections that the inspector was to carry out.

8 In 2018, the Defender of Rights, Jacques Toubon, reported 195 referrals between 2016 and 2018. See J. Toubon, Le regime general de protection des lanceurs d'alerte est-il l'expression d'un droit fundamental?, Semaine Sociale Lamy, 20 May 2019, No. 1862.

9 See O. Leclerc, Protéger les lanceurs d'alerte : la démocratie technique à l'épreuve de la loi, LGDJ, Paris 2017. Voir également, J. Schwartz Miralles, Le lancement d'alertes en droits français et américain, Doctorat, Université Aix-Marseille, 2019.

10 M.-A. Frison-Roche, L'impossible unicité juridique de la catégorie des lanceurs d'alerte, [in:] Chacornac J., Lanceurs d'alerte, regards comparatistes, Collection Centre Français de Droit Comparé, Vol. 21, 2019, pp. 13-31. 
As several authors have pointed out, this evolution is double-edged since by no longer characterising themselves as merely announcing a risk but also as denouncing a breach, whistleblowers become an instrument at the service of institutions to guarantee proper application of the law. ${ }^{11}$ This issue of effectiveness of the law appears clearly in the framework of the European directive, which refers to the interest of "effective detection, investigation and prosecution of breaches of Union law, thereby enhancing transparency and accountability" (Recital 3). This dimension coexists with the objective of "detecting and preventing, reducing or eliminating risks to public health and to consumer protection resulting from breaches of Union rules" (Recital 13). There are several figures of the whistleblower but the contemporary legal approach does not make any distinction among them.

In the context of this approach, the European directive only envisages whistleblowing in the professional context, since it is in this context that breach of the law is likely to be observed. The particularity of the French legislative framework with respect to the provisions of the directive is primarily due to a broadened scope of application that is not limited to a professional context. While the company or the workplace may appear at first glance to be the setting in which the alert takes place and needs to be protected, the French legislator has set criteria guaranteeing this protection that go beyond the sole professional context. This legislation is therefore bound to coexist with the alerts that French labour law has protected for several decades. The Labour Code effectively enshrines the so-called 'collective' right to alert insofar as this right is recognized for employee representatives. ${ }^{12}$ Four subjects of alert are defined: in case of infringement of personal rights (Article L. 2312-59 of the Labour Code), in case of serious and imminent danger (L. 2312-60), in economic matters (Article L. 2312-63) and in social matters (Article L. 2312-70 of the Labour Code). Started in 1982, the construction of this right to signal (which later became a right to alert) recognized to the staff representative bodies was progressive. It is first and foremost part of a desire to guarantee "the exercise of prerogatives of expression." 13 This collective alert coexists with the so-called individual alert within the company, which has a different purpose. ${ }^{14}$ The Labour Code provides that any worker must immediately alert the employer of any work situation which he or she has reasonable cause to believe presents a serious and imminent danger to his or her life or health, as well as of any defect that he or she observes in the protective systems. ${ }^{15}$ Also, following the law of 16 April $2013 n^{\circ} 2013-316$, a specific alert is provided if the worker believes in good faith that the products or manufacturing processes used or implemented by the establishment pose a serious risk to public

11 Ibidem.

12 Art. L2312-59 to L2312-71, Labour Code.

13 O. Leclerc, Protéger les lanceurs d'alerte: la démocratie technique à l'épreuve de la loi, op. cit., p. 23.

14 See J. Icard, L'alerte individuelle en droit du travail, Droit social, 2017, p. 54.

15 Article L. 4131-1. 
health or the environment. ${ }^{16}$ In the context of these alerts, the employer is the recipient of the report and the procedure is much less restrictive than that resulting from the general framework set out in the Sapin II Law. The coexistence of these different types of individual alerts poses some difficulties in the intelligibility of the French legal framework. It is difficult to grasp a unitary approach of French law with respect to the alert launched by the worker.

Regarding the legal basis for this protection, the French approach is now in line with the protection of freedom of expression. It is in this sense that the Defender of Rights conceives the protection of whistleblower: "the alert is first and foremost the manifestation of a fundamental individual freedom, the freedom of expression enshrined at the international, European and national levels." ${ }^{17}$ It is also in this sense that the Court of Cassation conceived it. Indeed, well before the adoption of the Sapin II Law, the Social Chamber of the Court of Cassation had affirmed this protection for employees denouncing acts deemed irregular in its decision of 30 June 2016. ${ }^{18}$ The judges had explained that "the fact for an employee to bring to the attention of the public prosecutor facts concerning the company which appear irregular to him, whether or not they are liable to penal qualification, does not in itself constitute a fault." Likewise, "because of the infringement of freedom of expression, in particular the right of employees to report unlawful conduct or acts observed by them in the workplace, the dismissal of an employee for having reported or testified in good faith about facts of which he became aware in the performance of his duties and which, if established, would be of such a nature as to constitute criminal offences, is null and void." 19 The approach here is extensive and marks a desire to place the protection of employees who report acts that they consider unlawful in the wake of the protection of fundamental rights. ${ }^{20}$ However, the legal framework resulting from the Sapin II Law remains quite restrictive with regard to this concept.

It is difficult to assess the impact of this legislation given its early date. The adoption of the European directive and the recent private Member's bills (Proposition de loi) submitted in the assembly ${ }^{21}$ nevertheless make it possible to highlight its

16 Article L. 4133-1.

$17 \mathrm{~J}$. Toubon, Le régime général de protection des lanceurs d'alerte est-il l'expression d'un droit fondamental?, Semaine Sociale Lamy, 20 May 2019, No. 1862.

18 Cass. Soc., 30 June 2016, No. 15-10557.

19 See the explanatory note of the Court of Cassation, which states that "the decision is in line with the decisions of the European Court of Human Rights, which consider that sanctions taken against employees who have criticized the functioning of a service or disclosed unlawful conduct or acts observed in the workplace constitute a violation of their right to expression", https://www.courdecassation.fr/jurisprudence_2/notes_explicatives_7002/protection_lanceurs_alerte_30.06.16_34751.html, accessed 01/09/2021.

20 See P. Adam, A propos de la protection générale des lanceurs d'alerte dans l'entreprise privée (Commentaire de la loi dite «Sapin Il» du 9 décembre 2016), Revue de jurisprudence sociale, 2017.

21 See Proposition de loi visant à la protection effective des lanceuses et des lanceurs d'alerte, 21 January 2020, https://www.assemblee-nationale.fr/dyn/15/textes/l15b2600_proposition-loi\#, accessed 01/09/2021. 
limitations and to consider the prospects for its development. ${ }^{22}$ The European Directive (EU) 2019/1937 would not bring significant progress for employees' rights since it limits its scope to the reporting of violations occurring in certain areas, which do not include those concerning the protection of workers' rights or failures in the application of European social legislation. If the purpose of the directive is above all to build a common framework for reporting violations of European Union law, it is surprising to note that European legislation applicable to health and safety at work, for example, is not included. ${ }^{23}$ However, it must be recognized that by targeting alerts launched in a professional context, workers are the first to be concerned by the European system thus designed.

The shortcomings of the current French legal framework are based on three issues. First, the scope of this protection must be defined more broadly (I) and the overly restrictive procedural framework must be corrected (II). The protections provided must also be strengthened (III). The question remains, however, whether it is possible to develop a unitary concept of the whistleblower when whistleblowing can pursue different purposes.

\section{A necessary revision of the scope of whistleblower protection in France}

\section{a) Limited protection due to the multiplicity of legal criteria for whistleblower qualification}

Breaches. The qualification criteria of the whistleblower were largely designed by the Sapin II Law. Article 6 of the Sapin II Law does not exactly define the alert but gives a legal qualification to the object of the signal implying the protection of the author. ${ }^{24}$ The object of the alert is understood here rather broadly since it may concern a "breach" of the law or a "threat". The French approach towards whistleblowing combines both the dimension of guaranteeing the effectiveness of the law (the whistleblower reacts

22 See A. Pitras, Le lanceur d'alerte: Etude comparée entre droit français et droit de l'Union européenne, Revue trimestrielle de droit européen, 2020, p. 181.

23 See. L. Robert, Vers un statut harmonisé du lanceur d'alerte - analyse critique de la directive sur la protection des personnes qui signalent des violations du droit de l'Union, [in:] Chacornac J., Lanceurs d'alerte, regards comparatistes, op. cit., p. 174.

24 Article 6 of the Sapin II Law: "A whistleblower is a natural person who discloses or reports, in a disinterested manner and in good faith, a crime or misdemeanour, a serious and manifest breach of an international commitment duly ratified or approved by France, of a unilateral act of an international organization taken on the basis of such a commitment, of the law or of the regulations, or a serious threat or prejudice to the general interest, of which he or she has had personal knowledge." 
to a breach of the law) and that of informing others about a risk (the whistleblower signals a threat). The alert is understood here as a revelation of information on illegal practices but also as information on the existence of a risk incurred.

However, the emphasis here is on the seriousness of the breach. The report must refer to a "serious breach" or "serious harm" or "serious threat". This severity is not specified. It will be assessed in the light of the general interest in the last two cases. For other violations, the seriousness of the breach will be assessed in the light of the legal requirements, except in the case of a crime or misdemeanour. In these two cases, the penal qualification of the offence is sufficient to lead to the protection of the person who reveals it. It must therefore be emphasized that, except in the case of a crime or misdemeanour, it is the person who makes the alert who must assess the seriousness of the breach he or she wishes to report. This is precisely the difficulty with this requirement, which could be a deterrent as it places the burden of assessing the seriousness of the breach on the person reporting it. ${ }^{25}$ In the hypothesis of a violation of a safety rule that would not be considered sufficiently important, this would imply that the person could not benefit from this qualification.

This dimension seems restrictive today but it was originally intended to open up the protected warning more widely to cases that do not fall within the scope of the criminal offence that was originally the only one targeted. Article L. 1132-3-3 of the French Labour Code, as drafted by Law 2013-1117 of 6 December 2013, only referred to employees who reported "facts constituting an offence or a crime of which they had knowledge in the performance of their duties." In a recent case, the Court of Cassation ruled out the qualification of whistleblower for a person who had broadcast a recording of an informal meeting with his employer during which the latter had mentioned the surveillance of correspondence to which trade unionists were subjected in the company. Under the law applicable in 2013, the Court found that it had not been established that the employee had reported or testified to facts that could constitute an offence or a crime. ${ }^{26}$

In this respect, the directive offers a distinct approach by targeting the violations concerned not with regard to their degree of seriousness but with regard to the areas in which they occur (Article 2). Breach is defined broadly in terms of the unlawfulness of the act or omission that contravenes the rules in the listed areas. It could be as well an act or omission that defeat the object or the purpose of the rules in the Union acts (Article 5). By offering a restrictive list of the areas concerned as well as the legal acts listed in the annex, the directive offers a more restrictive approach than the alert conceived in French law. ${ }^{27}$ However, for the areas concerned, the qualification will be broader than that provided for under French law, since this qualification

25 P. Adam, A propos de la protection générale des lanceurs d'alerte dans l'entreprise privée (Commentaire de la loi dite «Sapin Il» du 9 décembre 2016), Revue de jurisprudence sociale, 2017.

26 Cass. Soc., 4 November 2020, No. 18-15669.

27 See L. Robert, vers un statut harmonisé du lanceur d'alerte - analyse critique de la directive sur la protection des personnes qui signalent des violations du droit de l'Union, op. cit., p. 175. 
is not conditional on any seriousness. It may seem simpler in this case to identify the area of the protected alert based on a more objective approach. However, the assessment of unlawfulness may be just as unclear and difficult to characterise for the person reporting the violation. Recital 42 of the Directive emphasizes the need for "the concept of violation to include abusive practices, namely acts or omissions which do not appear to be unlawful in formal terms but which run counter to the object or purpose of the law."

Context of the alert. The system resulting from the Sapin II Law offers protection with the personal scope of application that is both precise and broadly circumscribed. Article 6 is aimed only at natural persons, and Article L1132-3-3 of the French Labour Code, which is a variation of this Article, is aimed not only at employees but also at candidates undergoing recruitment or a training period. As Article 6 is of a general nature, there is no exclusion in principle of self-employed workers or temporary workers from the scope of its application. Moreover, it is not necessary for the person to be acting in a professional context but to have personal knowledge of the facts he or she is reporting. The scope of application of the whistleblower status therefore excludes legal persons who cannot meet the criteria set to benefit from this protection. This limitation, in the context of labour, excludes in particular the role of trade unions as beneficiaries of this protection.

The European approach is more restrictive than the French framework, since it concerns persons who intervene in a professional context, with Article 4 providing a list of persons concerned. The concept is admittedly broad, since persons "working" in the private or public sector are included, in addition to employees. This interpretation is reinforced by Recital 39 of the Directive, which specifies that natural persons who are not employees in the legal sense of the term but who intervene in a "professional" context (such as suppliers, for example) may be concerned. The French legal framework is in line with this requirement since the approach is not limited to employees but to any natural person, without any reference to the professional context. The procedure provided for by the Sapin II Law suggests that the classic framework for whistleblowing is the professional framework because of the procedure it establishes for reporting such whistleblowing. However, this is not in itself a requirement for qualification, as the legislator has preferred to impose a "personal knowledge of the facts," which then appears to set an additional condition with regard to European law. This requirement of personal knowledge of the facts is understood as aiming to prevent the propagation of rumours.

Reasons for the alert. The question of the motivation of the whistleblower could appear essential since the classic representation is that of a virtuous and honest person denouncing a violation of the law for general interest. ${ }^{28}$ The approach chosen by the

28 See M.-A. Frison-Roche, L’impossible unicité juridique de la catégorie des «lanceurs d'alerte», op. cit., p. 14. 
legislator is the classic one in French law of a person acting in good faith, coupled with the condition of acting as a "disinterested" person. While this condition of "good faith" is specified in the regulatory texts with respect to public employees, ${ }^{29}$ nothing is said in the Labour Code. The judges of the Social Chamber of the Court of Cassation have had the occasion to specify that the bad faith of the whistleblower, when he denounces acts of harassment, should be understood as resulting from "the employee's knowledge of the falsity of the facts denounced and not from the sole circumstance that the facts denounced are not established." 30

This requirement of good faith is therefore not to be understood as a requirement of truthfulness with regard to the whistleblower but of ignorance of the possible falsity of the facts reported. Regardless of the motives of the whistleblower's action, in order to assess this good faith the information available to the whistleblower on the day of the denunciation must be taken into account and not his or her possible intention. The judges of the court may for instance characterise this good faith by noting that "it does not result from any of the elements of the file that (the employee) denounced facts that he knew to be false. It can be deduced from this that (the employee) was acting in good faith when he brought to light his suspicions about possible misappropriation of public funds by the employer." ${ }^{31}$ However, this condition is not always strictly assessed by the judges. In order to exclude the qualification of whistleblower, it has been judged that "good faith does not require that the facts denounced be subsequently established, but that they have been reported with honesty and loyalty and without any malicious intent." ${ }^{32}$ In this approach, good faith is likened with the search for the absence of defamation or malicious intent. Outside of employment litigation, this characterisation of good faith will be essential in the context of a possible defamation or slander action against the whistleblower. In this case, the judges will be even more demanding and other criteria will be taken into account to qualify good faith. ${ }^{33}$

This approach to good faith might seem far from the Anglo-Saxon approach taken by the European directive, which is primarily concerned with the whistleblower's "reasonable grounds" for believing that the information reported was true (Article 6.1). It is not a question of assessing the motivation of the whistleblower, since Recital 32 specifies that the motives of the author of the report should be irrelevant in

29 See Circulaire du 19 juillet 2018 relative à la procédure de signalement des alertes émises par les agents publics dans le cadre des articles 6 à 15 de la loi No.2016-1691 du 9 décembre 2016 relative à la transparence, à la lutte contre la corruption et à la modernisation de la vie économique, et aux garanties et protections qui leur sont accordées dans la fonction publique. The circular specifies that "the author must have a reasonably established belief in the truthfulness of the facts and acts that he intends to report with regard to the information to which he has access, and be devoid of any intention to harm."

30 Cass. Soc. 8 juillet 2020, No. 18-13593.

31 Cour d'Appel d'Agen, 26 January 2021, No. 19/00666.

32 Cour d'Appel d'Amiens, 9 January 2020, No. 18/00584.

33 Y. Pagnerre, Harcèlement, alerte et diffamation: enfin l'harmonie?, Dalloz, Paris 2016, p. 2447. 
determining whether protection should be granted to them. Rather, the approach would be to assess whether the whistleblower could validly believe in the truth of what he or she was reporting, in the light of the knowledge available at the time of reporting.

This could be similar to the French approach but French law adds the condition of a disinterested action to the condition of good faith. This condition is not always uniformly understood. It may imply the absence of material or financial interest behind the action. It can be more broadly understood as implying the absence of any personal involvement in the facts reported. The latter interpretation is not satisfactory in so far as it leads to a considerable reduction in the scope of the protection granted. In the Tefal case, the labour inspector who was in conflict with her superior was reproached by the judges for this personal involvement in the alert triggered. It was found that "she was denouncing an infringement of the principle of independence of labour inspectors, but she was the direct victim of the disturbance she intended to denounce. She did not denounce other facts, distinct from those concerning her personally, likely to constitute a threat or a serious prejudice for the general interest." 34 This other condition combined with the requirement of good faith leads judges to scrutinize the motives of the whistleblower. For example, the Amiens Court of Appeal considers that the purpose of the letter sent by the whistleblower "is a negotiated departure, for which the employee uses the means of blackmail, claiming the existence of fraudulent facts, not to denounce them in the interest of the collective good or of the company, but to achieve his own ends. This approach, which is opposed by nature to the launching of an alert, assuming the disinterested nature of the act, constitutes a major breach of the obligation of loyalty, making it immediately impossible to maintain the employment contract." 35 The conditions set out in French law concerning the motivation of the whistleblower seem much more restrictive than those set out in the Directive. The importance given to this condition appears to be highly questionable.

\section{b) The necessary extension of the personal scope of whistleblower qualification}

Legal entities. In the context of the future transposition of Directive (EU) 2019/1937, the opinions rendered are almost unanimous in deploring the restriction of the personal scope of application of whistleblowers to natural persons only and in defending the extension of the qualification of whistleblower to legal persons. ${ }^{36}$

34 Cour d'Appel de Lyon, 24 October 2019, No. 19/00554; A. Casado, Lanceur d'alerte: maturation ou estouffade, Bulletin Joly Travail, 2020, p. 44.

35 Cour d'Appel d'Amiens, 9 janvier 2020, No. 18/00584.

$36 \mathrm{CNCDH}$, Avis sur la transposition de la directive relative à la protection des lanceurs d'alerte, 24 September 2020, https://www.cncdh.fr/sites/default/files/avis_2020_-_11_-_avis_transposition_directive_lanceurs_dalerte.pdf, accessed 01/09/2021. 
They all recall that before the Sapin II Law, within the framework of the law of 16 April 2013, the right was established for "any natural or legal person" to make public or to disseminate in good faith information concerning a fact, data or an action, as soon as the ignorance of this fact, these data or this action seems to pose a serious risk for public health or on the environment (Article 1). This provision was repealed by the Sapin II Law, which now only targets natural persons.

Several arguments are used to defend this extension of the protection linked to the status of whistleblower. The first argument aims above all at underlining the role that certain legal entities such as NGOs or trade unions can play. The Defender of Rights affirms that this "would make it possible to give a collective character to the alert and thus to break the solitude in which the whistleblower often finds himself while limiting his exposure to the risks of reprisals." ${ }^{37}$ Indeed, trade unions are often called upon in the context of whistleblowing in a professional context. This was the case, for example, of the labour inspector who had sent the information she had gathered to report the alert directly to several union organizations outside the company. The question of reprisals that may be incurred by legal entities obviously arises differently than for natural persons, acting in particular in a professional context. Here, it is not a question of protecting them against possible exclusion from a recruitment process, for example. The idea is rather to extend the protection against abusive procedures or 'gagging' procedures that could be introduced against them.

However, trade unions have a somewhat different status, since for several decades French law has recognized a collective right to alert the employer of certain facts within the framework of the exercise of their functions. In this respect, they are protected by their function.

Facilitators. In the French legal context, it is not necessary for the person to act in a professional context (see the difference with the directive) but he or she must have personal knowledge of the facts that he or she reports. This condition is essential since it implies that the person has access to information which, if known, will enable a rapid reaction. However, its disadvantage is that it does not allow for the protection of third parties, i.e. the people who provide assistance to the whistleblower.

In this point, the Directive does take into account the role of third parties, i.e. the 'facilitators'. Recital 41 specifically envisages the protection of trade union representatives and workers' representatives under the protection provided by the Directive and envisages their intervention with the whistleblower in this respect by providing advice and assistance. Similarly, it is the "legal entity" to which the whistleblower belongs that is mentioned as a possible target of indirect reprisals. Article 4(c) of the Directive refers to "legal entities belonging to the whistleblowers or for which they work, or with which they are linked in a professional context." In an opinion issued in 2020, the Commission nationale consultative des droits de l'Homme considered "that the status of facilitator should be extended to any legal entity, in particular

37 Opinion of the Defender of Rights No. 20-12, 2020, p. 5. 
trade unions, non-profit associations and foundations." 38 Similarly, the Defender of Rights believes that "in the event that a representative of the legal entity is likely to be considered as a facilitator and benefit from the same protection regime as the author of the alert, the legal entity could not claim to benefit for itself from protection measures in the event of reprisals against it (removal of facilities for carrying out its activity, removal of subsidies...)." ${ }^{39}$ In particular, it encourages efforts "to clarify the role of legal persons in the process of launching alerts (NGOs, trade unions)." This element is also at the heart of the bill tabled in $2020 .{ }^{40}$ On this point, the transposition could therefore allow French law to apprehend the role of third parties more precisely in the framework of the protection granted to whistleblowers.

The scope of whistleblower protection in French law differs from that of the European Directive. The results of the application of these very restrictive conditions underline the need to reconsider these criteria. Similarly, the procedure put in place to guarantee the protection of whistleblowers appears too complex.

\section{The need to strengthen the guarantees regarding the modalities of the treatment of the alert}

\section{a) A hierarchical conception of alert processing}

Internal reporting. As conceived by the Sapin II Law, the whistleblower must follow a three-step procedure. The choice has been made to favour an internal reporting procedure, within the whistleblower's professional framework. Article 8 of the law provides that the whistleblower must bring the facts to the attention of the employer's direct or indirect superior or of a person designated by the latter. It is the responsibility of this person to verify the admissibility of the alert. On this basis, a decree dated 19 April 2017 specifies the procedures for collecting reports issued by whistleblowers within legal entities under public or private law or State administrations. ${ }^{41}$ More specifically, legal entities employing at least fifty employees are targeted in particular. In this context, they must establish an internal procedure

$38 \mathrm{CNCDH}$, Avis sur la transposition de la directive relative à la protection des lanceurs d'alerte, 24 September 2020, https://www.cncdh.fr/sites/default/files/avis_2020_-_11_-_avis_transposition_directive_lanceurs_dalerte.pdf, accessed 01/09/2021

39 Opinion of the Defender of Rights No. 20-12, 2020, p. 5.

40 Proposition de loi visant à la protection effective des lanceuses et des lanceurs d'alerte, 21 January 2020, https://www.assemblee-nationale.fr/dyn/15/textes/L15b2600_proposition-loi\#, accessed 01/09/2021.

41 Décret No. 2017-564 du 19 avril 2017 relatif aux procédures de recueil des signalements émis par les lanceurs d'alerte au sein des personnes morales de droit public ou de droit privé ou des administrations de l'Etat. 
for collecting reports and appoint a contact person with the competence, authority and resources required to carry out his/her duties. Alerts must be processed within a reasonable time. Article 5 of the decree states that the procedure for collecting alerts specifies the methods by which the author of the alert sends his or her report to the direct or indirect superior, the employer or the referent. However, no special procedure is specified in small structures, companies with less than 50 employees.

This first stage is therefore characterised by the legislator's desire to give priority to the internal handling of the alert, within a hierarchical framework, and not with regard to any particular capacity of expertise held by the recipient of the alert. It has been underlined in this sense that "the collection of alerts is embedded in a hierarchical network." ${ }^{2}$ Originally, it was the same body, the national commission of ethics and alerts in matters of public health and the environment, which ensured the transmission of alerts. The difficulties concerning the investigative powers of the commission led to a change in the institutional organization of this handling of alerts, entrusting it to the Defender of Rights in the framework of the Sapin II Law. Article 8 accepts that any person may send his or her report to the Defender of Rights, who may refer the whistleblower to the appropriate body.

This recourse to the Defender of Rights is only an alternative. Article 8 of the Sapin II Law favours a gradation in the reporting channels offered to whistleblowers. Only if the whistleblower's case is not dealt with internally can it be sent to the judicial or administrative authorities or to professional associations. If, after a period of three months, the alert has not been processed, the author of the alert is authorized to make it public. This hierarchy within the alert channels can only be bypassed in case of "serious and imminent danger or in the presence of a risk of irreversible damage." The observance of this procedure is a precondition for the benefit of the whistleblower's protection and in particular the absence of criminal responsibility. In this respect, the labour inspector in the 'Tefal case' was prosecuted for receiving stolen goods. The inspector in question, in conflict with her superior, had disclosed facts by forwarding e-mails she received to a higher authority and to the unions. In a referral ruling, the Court considered that the fact that she had not addressed the report to her hierarchy beforehand but to a third party, even though she was in conflict with one of the members of her hierarchy, resulted in the failure to comply with the reporting procedure, so that she could not hope for no criminal liability. According to the judges, she could have notified her regional or national director. ${ }^{43}$

The whole constraint of such a graduated system rests on this assessment of the treatment of the alert within a reasonable time. It seems very uncertain for the whistleblower to determine whether the time elapsed can be considered to constitute a reasonable time, especially since he or she may be in a particularly vulnerable situation due to the disclosure.

42 O. Leclerc, Protéger les lanceurs d'alerte: la démocratie technique à l'épreuve de la loi, op. cit., p. 65.

43 Cour d'Appel de Lyon, 24 October 2019, No. 19/00554. 
In this respect, the French legal framework differs from the European concept of reporting channels. Contrary to the wishes of the European Commission, the Directive, in its Article 7, provides for this purpose that member states "encourage" the use of internal reporting channels, while indicating that this should happen on condition that the author of the report believes that there is no risk of reprisals. It is therefore left to the whistleblower to assess which channel is the most appropriate one for the alert in view of the professional risk involved. Article 10 also states that the alert may be made internally or "directly through external reporting channels." It is also provided that these channels can be managed internally or by a service provided externally by a third party. Outsourcing of the collection of the alert is therefore conceivable.

Public disclosure. In this respect, French law appears to be far too restrictive in relation to the framework set by the European Directive. Indeed, the only exceptions allowing a public alert to assume either that it intervenes as a last resort or that the author of the alert is confronted with a serious and imminent danger or in the presence of a risk of irreversible damage (Article 8 of the Sapin II Law). The exceptions provided for in the Directive are more important since it also provides for this possibility, in the case of external reporting, if there is a risk of retaliation or if there is little chance that the violation will actually be remedied, due to the particular circumstances of the case, such as when evidence may be concealed or destroyed or when an authority may be in collusion with the perpetrator of the violation or implicated in the violation (Article 15). However, even if the public reporting route is more widely open, this option must be combined with the requirement of a professional context for the alert, so that it still seems rather risky for the person who discovers a violation in a professional context to report it publicly.

\section{b) The limits of the administrative treatment of the alert}

Recipient. In view of the difficulties posed by the gradation of reports in the French legal framework, it seems necessary to develop institutional support for whistleblowers. The many uncertainties created by the time required to follow up on the treatment imply that other means of recourse should be offered to the person who wishes to reveal a violation of the law. In this context, it seems even easier for the person who has made a report without respecting the procedure and who is subject to a disciplinary measure to argue that the freedom of expression has been infringed. The first recipient of the whistleblowing in the French approach is mainly the employer (informed through the referent or a hierarchical superior) but the situation of the whistleblower in the company may constitute a major obstacle to internal reporting. The Directive provides more precise elements concerning the follow-up of these alerts than the Sapin II Law does. It is stated that these channels must be "independent and autonomous" (Article 12). 
Beyond these procedural limits, the issue at stake is the handling of the alert by the Defender of Rights. The latter has the particularity of having a constitutional status. He intervenes to guide and inform the whistleblower. However, the problem is that of the means available to the Defender of Rights. A proposal has been made to create a general inspectorate for the protection of whistleblowers. ${ }^{44}$ The idea is to attach an inspectorate to the Defender of Rights that would be responsible for monitoring the treatment of whistleblowers. The missions of this inspectorate would focus on the reception and processing of whistleblowers. Information would also be provided by this inspectorate, which could also carry out an audit. The interest of such an inspectorate would lie in its composition: several commissions would compose this inspectorate and would be divided according to the fields of expertise.

Data protection. The issue of handling whistleblowing today essentially revolves around the protection of the confidentiality of the person who reports these violations. In French law, anonymity is not allowed, ${ }^{45}$ but confidentiality must be guaranteed: "The procedures implemented to collect alerts, under the conditions mentioned in Article 8, guarantee strict confidentiality of the identity of the authors of the alert, of the persons targeted by the alert and of the information collected by all of the recipients of the alert" (Article 9 of the Sapin II Law). This confidentiality is protected since disclosing the identity of the person and the information concerned is an offence. The law provides that this offence is punishable by two years of imprisonment and a fine of EUR 30,000. The procedure must therefore guarantee "strict confidentiality of the identity of the author" of the report. Despite this protection, the identity of the whistleblower will, by definition, be known by the recipient of the alert, which may constitute a significant obstacle to this approach. In this respect, the French National Commission for Information Technology and Civil Liberties (CNIL) published a reference framework "relating to professional alert systems (DAP)" in December 2019. In this framework, it reiterates the recommendation not to "encourage people who are intended to use the system to do so anonymously, it being understood that an anonymous alert is an alert whose author is neither identified nor identifiable." 46 The Commission notes, however, that "by exception, an alert from a person who wishes to remain anonymous should be treated under the following conditions: the seriousness of the facts mentioned is established and the factual elements are sufficiently detailed;

44 Proposition de loi organique visant à la création de l'inspection générale de la protection des lanceuses et lanceurs d'alerte, 15 January 2020.

45 There are however particular cases where anonymity will be allowed. See Article L. 634-1 of the Monetary and Financial Code, which authorizes anonymous reporting of breaches to certain persons.

46 See CNIL, Reference framework on the processing of personal data intended for the implementation of a professional alert system, 18 July 2019, p. 6. 
the treatment of this alert must be surrounded by particular precautions, such as a prior examination, by the first addressee, of the appropriateness of its dissemination within the framework of the system." ${ }^{47}$

\section{Whistleblower protection to be completed}

\section{a) Limited measures of protection}

Against retaliations. The general purpose of the legal framework relating to whistleblowers in France is, above all, to guarantee protection against possible reprisals. The confidentiality of the report and the lack of criminal responsibility in the event of violation of a secret protected by law are at the core of this protection. This protection is based on two pillars: a labour law component and a criminal law component. In this respect, the Directive cannot modify this state of the law since the European Union does not have the competence to impose criminal legislation concerning whistleblowers. ${ }^{48}$ In this regard, the Directive reserves the competence of the Member States with regard to criminal liability (Article $21 \$ 3$ ). Apart from the hypothesis that a criminal offence is recognized, the author of the alert does not incur any liability $(\$ 2)$.

In France, the protection of whistleblowers was conceived in the context of the fight against discrimination. ${ }^{49}$ Under the influence of European law and the transposition of the European Directives on equality, the rules aimed at protecting the author of a whistleblowing report against retaliatory measures have been designed according to the model of non-discrimination law. This is reflected first of all in the adaptation of the evidentiary rules. These have been adapted to facilitate the exercise of the warning, since Article L. 1132-3-3 of the Labour Code provides that "when the person presents factual elements that allow for the presumption that he or she has reported or testified in good faith about facts constituting an offence or a crime, or that he or she has reported an alert in compliance with Articles 6 to 8 of the aforementioned Act No. 2016-1691 of 9 December 2016, it is incumbent upon the defendant, in view of the elements, to prove that his or her decision is justified by objective elements unrelated to the statement or testimony of the person concerned. The judge shall form his or her opinion after ordering, if necessary, any investigative measures that he or she deems useful." In this context, the author of the measure must establish the elements on which his or her decision is based.

47 Ibidem.

48 J. Leblois-Happe, La protection pénale du lanceur d'alerte - réflexions théoriques et approche comparatiste, [in:] Chacornac J., Lanceurs d'alerte, regards comparatistes, op. cit., pp. 129-152.

49 O. Leclerc, Protéger les lanceurs d'alerte: la démocratie technique à l'épreuve de la loi, op. cit., p. 73. 
It is under the prohibition of discrimination that retaliatory measures are null and void. The same Article provides that no person may be subject to a discriminatory measure "for having reported or testified, in good faith, to facts constituting a misdemeanour or a crime of which he or she may have become aware in the performance of his or her duties" as well as "for having reported an alert in compliance with Articles 6 to 8 of Law 2016-1691 of 9 December 2016 on transparency, the fight against corruption and the modernization of economic life." This intertwining of the alert and discrimination implies that the person will only be protected if his or her situation falls within the cases listed by the legislator. This rises difficulties insofar as "the alert is useful precisely because it draws attention to events or risks that were not envisaged." ${ }^{50}$

Article 19 of the Directive, which lists the prohibited measures of retaliation in a restrictive manner, does not bring about any major change in this respect, since the approach adopted is also to target essentially retaliatory measures that may occur in a professional context. In this respect, Recital 44 of the Directive stresses the need for "a broad definition of the term retaliation, encompassing any act or omission in a professional context which causes prejudice to the whistleblowers." However, the list provided in Article 19 could lead to changes in the French legal framework since it refers broadly to "harm, including damage to the reputation of the person, in particular on social networks, or financial loss, including loss of business and loss of income."

As far as criminal law is concerned, the protection designed appears to be fragmentary. A specific system of protection has certainly been adopted within the framework of the Sapin II Law in view of the inadequacies of ordinary law. ${ }^{51}$ The whistleblower benefits from a special exemption from criminal liability if his or her report violates a secret protected by law. Article 122-9 of the Criminal Code, however, sets the condition of a "necessary and proportionate disclosure to safeguard the interests at stake." In addition to this, there is the condition of respecting the reporting procedures defined by the law. This is precisely the point at issue in the dispute between the labour inspector, who is being prosecuted for receiving stolen goods, and the Tefal company. The inspector, in conflict with her superior, disclosed the facts by forwarding e-mails she received to a higher authority and to the unions. In a referral ruling, the Court of Appeal considered that the fact that she had not addressed the report to her hierarchy beforehand but to a third party, even though she was in conflict with one of the members of her hierarchy, resulted in the failure to comply with the reporting procedure, so that she could not rely on criminal irresponsibility. ${ }^{52}$ According to the judges, she could have notified her regional director or her national director. This first procedural constraint appears very restrictive. In addition, it must be established that the report violates a protected secret, which is more restrictive than the confidentiality

50 Ibidem.

51 J. Leblois-Happe, La protection pénale du lanceur d'alerte - réflexions théoriques et approche comparatiste, op. cit. p. 129.

52 Cour d'Appel de Lyon, 24 October 2019, No. 19/00554; A. Casado, Lanceur d'alerte: maturation ou estouffade, Bulletin Joly Travail, 2020, p. 44. 
of information that would be broken. Any disclosure of information is not protected. Above all, as this criminal disclaimer is limited to the situation of a breach of secrecy, other criminal actions (defamation, theft...) against the whistleblower fall outside its scope.

It is true that actions aimed at hindering the launching of the alert, whether it is an obstacle to reporting or abusive legal action, are now more generally targeted. Article 13 of the Sapin II Law provides for a penalty of one year of imprisonment and a fine of EUR 15,000, but also a fine of EUR 30,000 for abusive or dilatory defamation claims. The approach is again very limited since this sanction is only aimed at one particular action, so that actions for receiving stolen goods, theft, are not included.

In this respect, the European Directive opens up an "immunity from liability" (Recital 92) which is intended to be very broad, taking into account the conditions under which the information was obtained. Article $21 \$ 7$ provides that "In legal proceedings, including those for defamation, infringement of copyright, breach of secrecy, infringement of data protection rules or disclosure of business secrets, or in respect of claims for compensation under private law, public law or collective labour law, the persons referred to in Article 4 shall not incur any liability as a result of alerts or public disclosures made pursuant to this Directive."

Specially protected secrets. Article 1 of the Sapin II Law provides that facts, information or documents, regardless of their form or medium, covered by national defence secrecy, medical secrecy or the secrecy of relations between a lawyer and his or her client are excluded from the whistleblower regime. There is also a specific regime for trade secrets. Trade secret is defined in Article L. 151-1 of the French Commercial Code. It covers any information meeting three criteria: it is not, in itself or in the exact configuration and assembly of its elements, generally known or easily accessible to persons familiar with this type of information because of their sector of activity; it has a commercial value, actual or potential, because of its secret nature; it is the object of reasonable protection measures, taking into account the circumstances, on the part of its legitimate holder, in order to preserve its secret character. An exception is provided for the disclosure of such a secret in the context of an alert, since it cannot be invoked if such disclosure occurs in the context of the exercise of the right to freedom of expression or to reveal, in order to protect the general interest and in good faith, an illegal activity, a fault or reprehensible behaviour, including when exercising the right to alert as defined in Article 6 of Law No. 2016-1691 of 9 December 2016 relating to transparency, the fight against corruption and the modernization of economic life.

\section{b) The need for material support}

Institutional support. In the current state of positive law, the most deficient part of whistleblower protection lies in the absence of real support measures provided for by the law. Support for whistleblowers is primarily conceived in terms of one 
institution, the Defender of Rights. Beyond this institution, there are few elements designed by the legislator to develop support measures for whistleblowers. The French approach is very different from the American one, since no financial reward is provided for. ${ }^{53}$ In the French conception, the whistleblower should be "disinterested" and a certain ethics would imply that he/she should not receive any financial compensation for this alert. This approach seems coherent, but as soon as the whistleblower is conceived in terms of a certain idea of compliance, ethics becomes less important than effective action. ${ }^{54}$

The possibility of financial support granted by the Defender of Rights was, however, originally foreseen by the legislator. The provision was censured by the Constitutional Council because of the competence of the Defender of Rights and not on the principle of the measure itself. It was thus ruled that "the mission entrusted by the aforementioned constitutional provisions to the Defender of Rights to ensure respect for rights and freedoms does not include the task of providing financial assistance, which might prove necessary, to persons who may refer cases to him. Consequently, the organic legislator could not, without disregarding the limits of the competence conferred on the Defender of Rights by the Constitution, provide that this authority could grant financial aid or financial assistance to the persons concerned". ${ }^{5}$

In the context of an opinion on the transposition of the European Directive, the Defender of Rights noted that "the Sapin II Law did not provide a sufficient framework for the conditions of handling and follow-up of alerts, which is a major obstacle to their development." ${ }^{56}$ She proposes to consider compensation for whistleblowers through "financial aid to compensate for the loss of income" 57 and the creation of a specific support fund intended to support whistleblowers facing difficulties or even legal aid without conditions given the qualification of whistleblower. In this respect, the measures envisaged in Article 4 of the Directive appear to be particularly important, since these support measures include "financial assistance and support measures, in particular psychological support, for whistleblowers in the context of legal proceedings," and these measures could be provided by an information centre or a single, clearly identified independent administrative authority. Above all, it is a matter of guaranteeing "effective assistance from the competent authorities before any relevant authority associated with their protection against reprisals."

Compensation. The other central aspect of support for whistleblowers that is also highlighted in the Directive concerns the question of compensation granted

53 See J. Schwartz Miralles, Le lancement d'alertes en droits français et américain, Doctorat, Université Aix-Marseille, 2019.

54 See M.-A. Frison-Roche, L'impossible unicité juridique de la catégorie des "lanceurs d'alerte», op. cit., p. 13

55 Conseil constitutionnel, décision No. 2016-740 DC, 8 December 2016, cons. 5.

56 Opinion of the Defender of Rights No. 20-12, 2020, p. 9.

57 Ibidem. 
to persons who are victims of measures taken against them as a result of reporting. In this sense, Recital 95 of the Directive emphasizes the need to "ensure real and effective compensation or reparation, in a way that is dissuasive and proportionate to the harm suffered." The Directive provides that the Member States must take "the necessary measures to ensure that remedies and full reparation are available for the damage suffered by the persons referred to in Article 4 in accordance with national law" (Article 21).

Under French labour law, a dismissal based on unlawful grounds may be null and void and the employee is entitled to reinstatement or to compensation. Nevertheless, since the adoption of an ordinance dated 22 September 2017, Article L1235-3-1 of the French Labour Code lists the grounds for nullity of dismissal, namely the violation of a fundamental freedom, acts of moral or sexual harassment under the conditions mentioned in Articles L. 1152-3 and L. 1153-4, discriminatory dismissal under the conditions mentioned in Articles L. 1132-4 and L. 1134-4, dismissal following legal action concerning professional equality between women and men under the conditions mentioned in Article L. 1144-3, or denunciation of crimes and offences. Provisions concerning retaliatory measures taken against a whistleblower are contained in Article L. 1132-3-3 which is not included in the causes listed in Article L. 1235-3-1.

However, violation of a fundamental freedom is a ground for nullity of the dismissal. It may be considered that the dismissal of a person who has made a whistleblowing report under the conditions provided for in Article 6 of the Sapin II Law would infringe the freedom of expression. In this respect, it may be possible to rely on the decision of the Labour Division of the Court of Cassation, which based the nullity of the dismissal pronounced "for having reported or testified, in good faith, to facts of which he had knowledge in the performance of his duties and which, if they were established, would be of such a nature as to characterise criminal offences" 58 on the infringement of the freedom of expression..$^{59}$ Very often, reprisals against the person who made the alert can also take the form of moral harassment and in this case dismissal will be declared null and void. This issue is important because if the dismissal is found to be without real and serious cause instead of being null and void, the employee will be subject to a scale of compensation and will therefore not be able to obtain full compensation. It should be noted that this issue is also addressed in Recital 95 of the Directive, which states that "the remedies introduced at national level should not discourage potential whistleblowers. For example, the granting of compensation as an alternative to reinstatement in the event of dismissal could lead to a systematic practice, particularly on the part of large organizations, which would have a dissuasive effect on future whistleblowers."

58 Soc. 30 June 2016, No. 15-10.557.

59 See P. Adam, Libertés fondamentales et barémisation: la grande évasion, Revue de droit du travail, 2017, p. 643. 


\section{Conclusions}

At the end of these four years of application of the law of 9 December 2016, the effectiveness of the protection designed for whistleblowers appears more than limited. The multiplicity of criteria to be met in order to benefit from this qualification is certainly one of the causes. The French legislator, while wanting to guarantee a specific mechanism for persons reporting a serious violation or a risk, has sought to limit inappropriate denunciations. By taking care to define the legal framework very precisely, it has at the same time made it too complex. In this respect, informing people about their rights and the steps to take is a real challenge in order to guarantee real protection for them. Beyond the qualification criteria, the procedure to be followed, by giving priority to the hierarchical framework, does not offer sufficient guarantees for the persons concerned. It is too uncertain and leads to increased vulnerability for those who undertake to disclose a violation.

In view of these various problems, the transposition of the European Directive offers the opportunity to remedy these shortcomings. On the one hand, by simplifying the criteria for qualifying as a whistleblower, it will make it possible to broaden the scope of application of the protection of individuals while making the legal framework more accessible. On the other hand, by opening up an alternative regarding the procedures to be implemented, it will make it possible to return to the gradation of channels that has been favoured by the French legislator.

It may be possible, however, to question the purpose of the legal framework that seeks to provide the same legislation for the steps taken by people who denounce violations of the law or who warn about health or environmental risks. By conceiving the whistleblower as a person who guarantees the correct application of the law and by seeking to establish a uniform framework of protection regardless of the subject of the alert, the French and European legislators have given the whistleblower a unique role. They are part of a compliance process and no longer a function of anticipating the damage that may result from any risk whatsoever.

The protection of whistleblowers was born, however, in the face of the many lawsuits brought against people to silence them. It is with regard to the extensive litigation of which they are victims that this protection must be conceived above all. As one author has underlined, "it should be remembered that the protection of whistleblowers appeared as a necessity in view of the trials they were subjected to." 60

\section{Abstract}

At first glance, the French legal framework for whistleblower protection may appear to be particularly well developed. Indeed, since the so-called Sapin II Law, it has offered general

60 O. Leclerc, Protéger les lanceurs d'alerte: la démocratie technique à l'épreuve de la loi, op. cit., p. 89. 
criteria to qualify a person as a whistleblower and set procedural and substantive guarantees against possible retaliatory measures. Although advanced, the system is not complete. Its shortcomings are repeatedly mentioned, to the extent that the transposition of European Directive (EU) 2019/1937 of 23 October 2019 is an opportunity to correct the limitations of the current system. No matter if the criteria may be too restrictive, the procedure too constraining or the protective measures insufficient, there are many elements that need to be modified. However, a question may arise as to whether a unitary treatment of the alert is possible when it does not always serve the same purpose.

\section{Bibliography}

Adam P., Libertés fondamentales et barémisation: la grande évasion, Revue de droit du travail, 2017.

Adam P., A propos de la protection générale des lanceurs d'alerte dans l'entreprise privée (Commentaire de la loi dite «Sapin II » du 9 décembre 2016), Revue de jurisprudence sociale, $5 / 2017$.

Alibert J., Foegle J.-F, Première victoire d'un lanceur d'alerte en référé sous l'empire de la loi « Sapin II », La Revue des droits de l'homme [En ligne], Actualités Droits-Libertés, https:// journals.openedition.org/revdh/6313, accessed 01/09/2021.

Casado A., Lanceur d'alerte : maturation ou estouffade, Bulletin Joly Travail, 2020, p. 44.

Chacornac J. (dir.), Lanceurs d'alerte, regards comparatistes, Collection Centre Français de Droit Comparé, Vol. 21, 2019.

Frison-Roche M.-A., L'impossible unicité juridique de la catégorie des lanceurs d'alerte, [in:] Chacornac J. (dir.), Lanceurs d'alerte, regards comparatistes, Collection Centre Français de Droit Comparé, Vol. 21, 2019.

Icard J., L'alerte individuelle en droit du travail, Droit social, 2017.

Leblois-Happe J., La protection pénale du lanceur d'alerte - réflexions théoriques et approche comparatiste, [in:] Chacornac J. (dir.), Lanceurs d'alerte, regards comparatistes, Collection Centre Français de Droit Comparé, Vol. 21, 2019.

Leclerc O., Protéger les lanceurs d’alerte: la démocratie technique à l'épreuve de la loi, LGDJ, Paris 2017.

Pagnerre Y., Harcèlement, alerte et diffamation : enfin l'harmonie ?, Dalloz, Paris 2016.

Pitras A., Le lanceur d'alerte: Etude comparée entre droit français et droit de l'Union européenne, Revue trimestrielle de droit européen, 2020.

Robert L., Vers un statut harmonisé du lanceur d'alerte - analyse critique de la directive sur la protection des personnes qui signalent des violations du droit de l'Union, [in:] Chacornac J. (dir.), Lanceurs d'alerte, regards comparatistes, Collection Centre Français de Droit Comparé, Vol. 21, 2019.

Schwartz Miralles J., Le lancement d’alertes en droits français et américain, Doctorat, Université Aix-Marseille, 2019.

Toubon J., Le regime general de protection des lanceurs d'alerte est-il l'expression d'un droit fundamental?, Semaine Sociale Lamy, 20 May 2019. 